\title{
Seasonal Variations of the Nutritive Value and Phytotherapeutic Potential of Cladium mariscus L. (Pohl.) Targeting Ruminant's Production
}

\author{
Marta Oliveira ${ }^{1}$, Maria João Rodrigues ${ }^{1}$, Nuno R. Neng ${ }^{2}$, José Manuel Florêncio Nogueira ${ }^{2} \mathbb{D}$, Rui J. B. Bessa $^{3}(\mathbb{D}$ \\ and Luísa Custódio $1, *$ (D) \\ 1 Centre of Marine Sciences, Universidade do Algarve, Campus de Gambelas, 8005-139 Faro, Portugal; \\ mmfoliveira11@gmail.com (M.O.); mary_p@sapo.pt (M.J.R.) \\ 2 Centro de Química Estrutural, Faculdade de Ciências, Universidade de Lisboa, Campo Grande, \\ 1749-016 Lisboa, Portugal; ndneng@fc.ul.pt (N.R.N.); jmnogueira@fc.ul.pt (J.M.F.N.) \\ 3 CIISA-Centro de Investigação Interdisciplinar em Sanidade Animal, Faculdade de Medicina Veterinária, \\ Universidade de Lisboa, Avenida da Universidade Técnica, 1300-666 Lisboa, Portugal; \\ rjbbessa@fmv.ulisboa.pt \\ * Correspondence: lcustodio@ualg.pt
}

Citation: Oliveira, M.; João Rodrigues, M.; Neng, N.R.; Nogueira, J.M.F.; Bessa, R.J.B.; Custódio, L. Seasonal Variations of the Nutritive Value and Phytotherapeutic Potential of Cladium mariscus L. (Pohl.) Targeting Ruminant's Production. Plants 2021, 10, 556. https:// doi.org/10.3390/plants10030556

Academic Editor: Filippo Maggi

Received: 8 February 2021

Accepted: 10 March 2021

Published: 16 March 2021

Publisher's Note: MDPI stays neutral with regard to jurisdictional claims in published maps and institutional affiliations.

Copyright: (c) 2021 by the authors. Licensee MDPI, Basel, Switzerland. This article is an open access article distributed under the terms and conditions of the Creative Commons Attribution (CC BY) license (https:// creativecommons.org/licenses/by/ $4.0 /)$.

\begin{abstract}
In our endeavor to identify salt-tolerant plants with potential veterinary uses in ruminants' production strategies, we focused on Cladium mariscus L. Pohl (sawgrass), due to its high total phenolic and tannin content, anti-radical properties, and ethnomedicinal uses. Aerial parts were collected along the year in Southern Portugal and evaluated for the nutritional profile and in vitro organic matter digestibility (IVOMD), aiming for its use as feed. Acetone extracts were appraised for total contents in phenolics (TPC), flavonoids (TFC), and tannins (CTC), as well as the chemical composition by HPLC-DAD and in vitro antioxidant and anti-inflammatory properties, targeting its exploitation as phytotherapeutic products. Sawgrass biomass has a limited nutritive value, due to its high neutral detergent fiber (NDF; 596-690 $\mathrm{g} \mathrm{kg}^{-1}$ dry matter (DM)) and acid detergent fiber (ADF; $\left.330-418 \mathrm{~g} \mathrm{~kg}^{-1} \mathrm{DM}\right)$ contents, low crude protein (51.8-87.3 $\left.\mathrm{g} \mathrm{kg}^{-1} \mathrm{DM}\right)$ and IVOMD (172-317 $\mathrm{g} \mathrm{kg}^{-1}$ organic matter $(\mathrm{OM}))$. Despite differences among seasons, the mineral profile was adequate. The extracts were rich in TPC (88-112 $\left.\mathrm{mg} \mathrm{g}^{-1}\right)$, CTC (115-169 $\left.\mathrm{mg} \mathrm{g}^{-1}\right)$, and TFC (18.5-20.2 $\left.\mathrm{mg} \mathrm{g}^{-1}\right)$, and displayed significant antioxidant capacity, particularly in summer and autumn, whilst no seasonal influence was detected for anti-inflammatory properties (30\% reduction of nitric oxide production). Eleven phenolics were quantified: chlorogenic, ferulic, and syringic acids were the most abundant, especially in the autumn sample. Overall, despite the low nutritional interest, sawgrass extracts hold the potential as a source of antioxidant and anti-inflammatory phenolic compounds.
\end{abstract}

Keywords: salt-tolerant plants; nutritional profile; phenolics; antioxidant; anti-inflammatory; veterinary

\section{Introduction}

Climate changes will have a strong impact on the Mediterranean area by significantly increasing drought, temperature, and evapotranspiration by the end of the 21st century [1,2]. This will negatively affect the agriculture and animal production by leading to soil and water salinization and degradation, freshwater scarcity, reduced crops yield and quality, and livestock losses [3].

Ruminants have a significant role in the Mediterranean Basin, and their production depends on costly feed supplementation strategies, mostly due to feed shortages during dry seasons [4]. The use of biomass from plants well adapted to that area's constraints is considered an important strategy to reduce the costs associated with feed supplementation $[5,6]$. Moreover, there is an increasing effort to reduce the use of synthetic substances in livestock production, as supported by the European Parliament and Council (Regulation (EC) no. 1831/2003; Regulation (EC) no. 834/2007). This drives the interest on searching 
for bioactive plants and its products, such as salt-tolerant plants, as alternatives for the improvement of animal nutrition, health, and quality of its derived food products.

Salt-tolerant plants are adapted to several abiotic stresses, including high salinity and UV intensity and drought, in part due to the synthesis and accumulation of bioactive primary and secondary molecules with an important nutritive value and relevant biological properties, including antioxidant and anti-parasitic [7]. Some species are already used as feed resources in arid and semi-arid regions of the Mediterranean basin, for grazing animals, especially under drought conditions or to couple with seasonal pasture scarcity (e.g., Sporobolus sp.) [5]. Other species have ethnoveterinary uses [8], for example, Pistacia lentiscus L., as antiparasitic and for the treatment of bloat, constipation, and dermatological ailments. These plants are also characterized by high total levels of phenolic compounds, including tannins and flavonoids [9]. This latter aspect is particularly relevant, since plants with a high content of such compounds can, depending on the dose, exert multiple beneficial effects on animal health and performance, including anti-inflammatory, antioxidant, and anthelmintic effects, reduction of methane production, modulation of ruminal biohydrogenation, and improvement of the fatty acid content of meat products [6,10-15]. Therefore, salt-tolerant plants hold a high potential to be explored to develop novel nutritional and health management strategies for animal farming systems, especially in the context of climate change and soil and water salinization.

Cladium mariscus (L.) Pohl (Cyperaceae, sawgrass) is a perennial evergreen plant occurring in inland areas and coastal saltmarshes in the Mediterranean area and North Africa [16]. In ethnomedicine, it has been used to treat colds, renal pain, and colic in the gastrointestinal tract $[17,18]$. A previous screening of 21 extremophile plants from Southern Portugal identified C. mariscus leaves as a polyphenol-rich species and with strong antiradical properties [9]. Nevertheless, to the best of our knowledge, the chemical assets and potential biological effects of sawgrass, as well as its seasonal variations were not priorly investigated. In this work, we hypothesized that this species could present interest for use as animal feed and/or to provide bioactive veterinary products to be included as part of production strategies to improve ruminants' overall health. Thus, we conducted a nutritional evaluation to ruminants of $C$. mariscus biomass collected along the year coupled with a chemical and biological characterization of its extracts.

\section{Material and Methods}

\subsection{Plant Collection and Processing}

Sawgrass aerial parts (voucher code no. XBH03), including leaves and inflorescences, were manually harvested in Ludo, Faro, Southern Portugal $\left(37^{\circ} 01^{\prime} 03.3^{\prime \prime} \mathrm{N}, 7^{\circ} 59^{\prime} 18.1^{\prime \prime} \mathrm{W}\right)$ in spring (April 2017), summer (July 2017), autumn (October 2017), and winter (January 2018). Inflorescences were noted during summer and, to a lesser extent, in autumn, while green leaves were present all year. After collection, the samples were taken to the laboratory, washed, frozen at $-20^{\circ} \mathrm{C}$, freeze-dried using a lyophilizer (Lyoalfa 15), and grinded using a ball miller (Retsch PM 100).

\subsection{Nutritional Analysis}

\subsubsection{Nutritional Profile}

Moisture was determined by drying fresh biomass in a ventilated oven at $105{ }^{\circ} \mathrm{C}$ for $16 \mathrm{~h}$. Freeze-dried and ground samples were analyzed for ash, by incinerating samples in a muffle furnace for $2 \mathrm{~h}$ at $600{ }^{\circ} \mathrm{C}$ [19], crude protein (CP), by measuring total nitrogen (N) in a CHN Elemental Analyzer (Vario EL III), and estimated by multiplying the $\mathrm{N}$ content by a factor of 6.25. Total lipids (TL) were determined according to a modified protocol of the Bligh and Dyer (1959) method [20], while the neutral detergent fiber (NDF), acid detergent fiber (ADF), and acid detergent lignin (ADL) were determined in agreement with the International Organization for Standardization (ISO) directives for analyzing animal feedstuffs (ISO 16472:2006, ISO 13906:2008, and ISO 13906:2008, respectively). Cellulose 
and hemicellulose contents were estimated by the difference between ADF and ADL or NDF and ADF, respectively.

\subsubsection{Mineral Content}

Minerals were assessed by the microwave plasma-atomic emission spectrometer (MPAES; Agilent 4200 MP-AES, Agilent Victoria, Australia), as described by Pereira et al. [21]. In sum, after digestion of ash samples for three times by the addition of nitric acid (67-69\%) and hydrogen peroxide (30\%) until complete evaporation, the dry digested samples were diluted in a known volume of $5 \%$ nitric acid solution for analysis. Results were expressed as $\mathrm{g} \mathrm{kg}^{-1}$ of dry matter (DM) for macro-minerals and $\mathrm{mg} \mathrm{kg}^{-1} \mathrm{DM}$ for trace minerals.

\subsubsection{In Vitro Organic Matter Digestibility (IVOMD)}

IVOMD was determined by the Tilley and Terry method modified by Alexander and McGowan [22]. Briefly, $500 \mathrm{mg}$ of ground samples weighed to incubation flasks, in triplicate, and incubated at $39^{\circ} \mathrm{C}$ for $48 \mathrm{~h}$ with $10 \mathrm{~mL}$ of rumen liquor and $40 \mathrm{~mL}$ of McDougall buffer. After this first incubation stage, the fermentation was stopped by adding $2.2 \mathrm{~N} \mathrm{HCl}$ and then incubated with $50 \mathrm{~mL}$ of an acid pepsin solution for an additional $48 \mathrm{~h}$. At the end, the residue obtained after filtration in a G2 crucible was dried at $105^{\circ} \mathrm{C}$, incinerated at $500^{\circ} \mathrm{C}$, weighed, and used to compute the IVOMD. The results of the method are calibrated using blank and standard feeds tests incubated simultaneously with the tested feedstuffs and the results are presented as $\mathrm{g} \mathrm{kg}^{-1}$ of organic matter (OM).

\subsection{Chemical Profiling of the Extracts}

\subsubsection{Preparation of the Extracts}

Dried samples were extracted with an 80:20 acetone:water solution $(1: 40, w / v)$ at room temperature (RT) for $16 \mathrm{~h}$, under stirring. The residue was filtered (Whatman no. 4) and concentrated in a rotary evaporator under reduced pressure and temperature (approximately $40^{\circ} \mathrm{C}$ ). Dried extracts were dissolved in dimethyl sulfoxide (DMSO) at a concentration of $25 \mathrm{mg} \mathrm{mL}^{-1}$ and stored at $-20{ }^{\circ} \mathrm{C}$ until use.

\subsubsection{Total Phenolic Content (TPC)}

The TPC of the extracts was estimated using the Folin-Ciocalteau (F-C) reagent [23], as described previously [24]. Briefly, $5 \mu \mathrm{L}$ of the extracts $\left(10 \mathrm{mg} \mathrm{mL}^{-1}\right)$ were mixed with $100 \mu \mathrm{L}$ of the F-C reagent (1:10 in water, $v / v)$ in 96-well plates, and left for $10 \mathrm{~min}$ at RT, in the dark. Then, $100 \mu \mathrm{L}$ of sodium carbonate $\left(75 \mathrm{~g} \mathrm{~L}^{-1}\right.$, in water) were added and the plate was incubated for $90 \mathrm{~min}$, at RT, protected from light. Absorbance was measured at $725 \mathrm{~nm}$ in a multiplate spectrophotometer reader (Biotek Synergy 4). A calibration curve was prepared using gallic acid as a standard and TPC was expressed as gallic acid equivalents (GAE; mg GAE g extract ${ }^{-1}$, dry weight (DW)).

\subsubsection{Total Flavonoid Content (TFC)}

TFC was determined by the aluminum chloride (AlCl3) method [25]. Briefly, $50 \mu \mathrm{L}$ of the samples at $10 \mathrm{mg} \mathrm{mL}^{-1}$ were mixed with $50 \mu \mathrm{L}$ of $2 \% \mathrm{AlCl}_{3}$ in a methanol and left to incubate for $10 \mathrm{~min}$ at RT. Absorbance was measured at $415 \mathrm{~nm}$ in a multiplate spectrophotometer reader. A calibration curve was prepared using quercetin as a standard and TFC was expressed as quercetin equivalents (QE; mg QE g extract $\left.{ }^{-1}, \mathrm{DW}\right)$.

\subsubsection{Total Condensed Tannins Content (CTC)}

CTC was evaluated by the 4-dimethylaminocinnamaldehyde-hydrochloric acid (DMA CA-HCl) colorimetric method [26] adapted to 96-well microplates [24]. In brief, $10 \mu \mathrm{L}$ of the extracts $\left(10 \mathrm{mg} \mathrm{mL}^{-1}\right)$ were mixed with $200 \mu \mathrm{L}$ of a methanol solution of DMACA $(1 \%, w / v)$, and $100 \mu \mathrm{L}$ of hydrochloric acid $(37 \%, v / v)$. After a $15 \mathrm{~min}$ incubation period, absorbance was measured at $640 \mathrm{~nm}$ in a multiplate spectrophotometer reader. A calibration 
curve was prepared using catechin as a standard and the concentration of CT was expressed as catechin equivalents (mg CE extract $\left.{ }^{-1}, \mathrm{DW}\right)$.

\subsubsection{Phenolic Profile by High Performance Liquid Chromatography-Diode Array Detection (HPLC-DAD)}

The extracts at a concentration of $10 \mathrm{mg} \mathrm{mL}^{-1}$ in a mixture of $90 \%$ ultrapure water and 10\% methanol were analyzed by HPLC-DAD (Agilent 1100 Series LC system, Germany). Analyses were performed on a MediterraneaTM sea 18 column, $15 \times 0.21 \mathrm{~cm}^{2}, 5 \mu \mathrm{m}$ particle size (Teknokroma, Spain). The mobile phase consisted of a mixture of methanol (solvent $\mathrm{A}$ ) and 2.5\% acetic acid aqueous solution with the following gradient: $0-5$ min: 10\% A, 5-10 min: 10-30\% A, 10-40 min: 30-90\% A, 40-45 min: 90\% A, 45-55 min: 90-10\% A, and 55-60 $\mathrm{min}: 10 \% \mathrm{~A}$, using a flow of $0.35 \mathrm{~mL} \mathrm{~min}^{-1}$. The injection volume was $20 \mu \mathrm{L}$ with a draw speed of $200 \mu \mathrm{L} / \mathrm{min}$. The detector was set at 210, 280 (used for quantification), 320 , and $350 \mathrm{~nm}$. For identification, the retention parameters of each assay were compared with the standard controls and the peak purity with the UV-visible spectral reference data. The levels of the different compounds were interpolated from calibration standard curves. Commercial standards of naringenin-7-glucoside, luteolin-7-o-glucoside, flavone, rutin, quercetin, catechin hydrate, epigallocatechin gallate, epicatechin, gallic acid, gentisic acid, p-hidroxybenzoic acid, vanillic acid, syringic acid, salicylic acid, ellagic acid, cafeic acid, coumaric acid, ferulic acid, rosmarinic acid, and chlorogenic acid were prepared in methanol $\left(1 \mathrm{~g} \mathrm{~L}^{-1}\right)$ and diluted with ultrapure water in the desired concentration.

\subsection{Bioactive Properties}

\subsubsection{In Vitro Antioxidant Properties}

In all the assays, the extracts were tested in serial diluted concentrations $(10,5,2.5$, $\left.1.25,0.625,0.3125,0.156,0.078 \mathrm{mg} \mathrm{mL}^{-1}\right)$, in order to enable the computing and calculation of the half maximal inhibitory concentration ( $\mathrm{IC}_{50}$ value). Absorbances were measured in a multiplate spectrophotometer reader (Biotek Synergy 4). Except for the ferric reduction antioxidant power (FRAP) assay, where results were calculated in relation to the positive control, results were expressed as a percentage of inhibition in relation to the negative control (DMSO) and as $\mathrm{IC}_{50}$ values $\left(\mathrm{mg} \mathrm{mL}^{-1}\right)$, whenever possible.

\section{Radical Scavenging Activity (RSA) on DPPH• Free Radical}

The RSA on DPPH• free radical was determined as described elsewhere [24]. Briefly, $22 \mu \mathrm{L}$ of the extracts were mixed with $200 \mu \mathrm{L}$ of a methanol DPPH solution $(120 \mu \mathrm{M})$ and left to incubate at RT in the dark. After $30 \mathrm{~min}$, absorbance was measured at $517 \mathrm{~nm}$. Butylated hydroxytoluene (BHT; $1 \mathrm{mg} \mathrm{mL}^{-1}$ ) was used as the positive control.

\section{RSA on ABTS•+ Free Radical}

The RSA on ABTS radical was determined as described previously [24]. A stock solution of ABTS• $+(7.4 \mathrm{mM})$ was prepared by mixing ABTS with potassium persulfate (2.6 mM, in water) for $16 \mathrm{~h}$ in the dark, at RT. For the assay, $10 \mu \mathrm{L}$ of the extracts, were added to 96 -well plates, mixed with $190 \mu \mathrm{L}$ of the ABTS• + solution and incubated at RT, for $6 \mathrm{~min}$, in the dark. Absorbance was measured at $734 \mathrm{~nm}$ and BHT $\left(1 \mathrm{mg} \mathrm{mL}^{-1}\right)$ was used as the positive control.

\section{RSA on Superoxide Anion $\left(\mathrm{O}_{2}{ }^{-} \bullet\right)$}

The RSA towards $\mathrm{O}_{2}{ }^{-} \bullet$ was evaluated according to the method described before [27]. In brief, $100 \mu \mathrm{L}$ of the extracts were mixed with $50 \mu \mathrm{L}$ of Tris-HCl buffer (16 mM; pH 8.0), $50 \mu \mathrm{L}$ of nitroblue tetrazolium $(0.3 \mathrm{mM}$ in Tri-HCl buffer), $50 \mu \mathrm{L}$ of nicotinamide adenine dinucleotide solution $(0.936 \mathrm{mM}$ in a solution of sodium hydroxide $5 \mathrm{mM})$, and $50 \mu \mathrm{L}$ of phenazine methosulfate $(0.12 \mathrm{mM}$ in ultrapure water), were left to incubate for $5 \mathrm{~min}$ at RT. Absorbance was measured at $560 \mathrm{~nm}$ and ascorbic acid $\left(1 \mathrm{mg} \mathrm{mL}^{-1}\right)$ was used as the positive control. 


\section{Metal Chelating Activity on Copper (CCA) and Iron (ICA)}

CCA and ICA were assayed as described elsewhere [24,28]. For CCA, the extracts $(30 \mu \mathrm{L})$ were mixed with $200 \mu \mathrm{L}$ of $50 \mathrm{mM} \mathrm{Na}$ acetate buffer $(\mathrm{pH}$ 6), $6 \mu \mathrm{L}$ of pyrocatechol violet $(4 \mathrm{mM})$ in the buffer, and $100 \mu \mathrm{L}$ of copper sulfate pentahydrate (CuSO4.5H20; $50 \mu \mathrm{g} \mathrm{mL}^{-1}$, in distilled water). Absorbance was measured at $632 \mathrm{~nm}$. For ICA, extracts $\left(30 \mu \mathrm{L} ; 10 \mathrm{mg} \mathrm{mL}^{-1}\right.$ ) were mixed with $200 \mu \mathrm{L}$ of distilled water and $30 \mu \mathrm{L}$ of $\mathrm{FeCl}_{2}$ solution $\left(0.1 \mathrm{mg} \mathrm{mL}^{-1}\right.$ in distilled water) and left to incubate for $30 \mathrm{~min}$, before adding $12.5 \mu \mathrm{L}$ of ferrozine ( $40 \mathrm{mM}$ in distilled water). Absorbance was measured at $562 \mathrm{~nm}$ and ethylenediamine tetraacetic acid (EDTA; $1 \mathrm{mg} \mathrm{mL}^{-1}$ ) was used as the positive control.

\section{Ferric Reducing Antioxidant Power (FRAP)}

FRAP was determined as described by Rodrigues et al. [24]. Samples $(50 \mu \mathrm{L})$ were mixed with distilled water $(50 \mu \mathrm{L})$ and potassium ferricyanide $(1 \%$ in water; $50 \mu \mathrm{L})$ and incubated for $20 \mathrm{~min}$ at $50{ }^{\circ} \mathrm{C}$. Then, $50 \mu \mathrm{L}$ of trichloroacetic acid $(10 \%$ in water, $w / v)$ and the ferric chloride solution $(0.1 \%$ in water, $w / v)$ were added. Absorbance was measured at $700 \mathrm{~nm}$ in a multiplate reader and results were expressed as a percentage in relation to the positive control (ascorbic acid, $1 \mathrm{mg} \mathrm{mL}^{-1}$ ), and as $\mathrm{IC}_{50}$ values $\left(\mathrm{mg} \mathrm{mL}^{-1}\right.$ ).

\subsection{In Vitro Anti-Inflammatory Properties}

\subsubsection{Cell Viability}

The murine leukemic monocyte-macrophage cell line (RAW264.7) was provided by the Faculty of Pharmacy and Centre for Neurosciences and Cell Biology (University of Coimbra, Portugal). Cells were maintained in a RPMI culture medium supplemented with $10 \%$ heatinactivated FBS, $1 \%$ L-glutamine $(2 \mathrm{mM})$, and $1 \%$ penicillin $\left(50 \mathrm{UmL}^{-1}\right) /$ streptomycin $\left(50 \mu \mathrm{g} \mathrm{mL}{ }^{-1}\right)$ at $37^{\circ} \mathrm{C}$ in humidified atmosphere with $5 \% \mathrm{CO}_{2}$. Exponentially growing cells were plated in 96-well tissue plates at a concentration of $1 \times 104$ cells/well and incubated for $24 \mathrm{~h}$ to allow macrophages adhesion. Extracts were then applied at $100 \mu \mathrm{g} \mathrm{mL} \mathrm{L}^{-1}$ and the plate was incubated for $24 \mathrm{~h}$ at $37^{\circ} \mathrm{C} 5 \% \mathrm{CO}_{2}$. Control cells were treated with DMSO at the highest concentration used in test wells $(0.5 \%)$. Cell viability was determined using the MTT reagent [29]. In brief, $2 \mathrm{~h}$ prior to the end of the incubation period, $20 \mu \mathrm{L}$ of MTT ( $5 \mathrm{mg} \mathrm{mL}^{-1}$ in PBS) were added to each well, followed by $150 \mu \mathrm{L}$ of DMSO, to dissolve the formazan crystals. Absorbance was measured at $590 \mathrm{~nm}$ in a multiplate reader. Results are expressed as a percentage of cell viability relative to a control containing DMSO $(0.5 \% v / v)$.

\subsubsection{In Vitro Anti-Inflammatory Properties}

The nitric oxide (NO) production by lipopolysaccharide (LPS)-stimulated RAW 264.7 macrophages was evaluated as described by Rodrigues et al. [30]. Cells were plated at $2.5 \times 105$ cells $/ \mathrm{mL}$ in 96-well tissue plates and allowed to adhere for $24 \mathrm{~h}$. Extracts were then applied at $100 \mu \mathrm{g} \mathrm{mL}^{-1}$, in a serum- and phenol-free culture medium, containing LPS (100 ng mL $\left.{ }^{-1}\right)$, and plates were incubated for $24 \mathrm{~h}$. A calibration curve was prepared using sodium nitrite as a standard and NO production was assessed using the Griess method [31]. Briefly, $100 \mu \mathrm{L}$ of samples supernatant were mixed with $100 \mu \mathrm{L}$ of the Griess reagent $(1 \%(w / v)$ sulphanilamide $+0.1 \%$ of NED and $2.5 \%(v / v)$ phosphoric acid) and left to incubate for $20 \mathrm{~min}$ at RT in the dark. Results were expressed as a percentage (\%) of NO production, in comparison to the non-treated LPS-stimulated control cells $(0.5 \%, v / v)$. L-NG-Nitroarginine methyl ester (L-NAME) is a nitric oxide synthase inhibitor and was used as the positive control.

\subsection{Statistical Analysis}

All the experiments were performed, at least, in duplicate. Data concerning the nutritional profile, IVOMD, and mineral content of the biomass are expressed as mean. The phenolic content and nitric oxide production results are expressed as mean \pm standard error of the mean (SEM), while results on the antioxidant properties are expressed as the concentration that results in a $50 \%$ inhibition $\left(\mathrm{IC}_{50}\right) . \mathrm{IC}_{50}$ values were obtained by 
sigmoidal fitting of the data, using the GraphPad Prism Software v.5.0. Seasonal effects were analyzed using the IBM SPSS Statistics v. 20.0 software, by analysis of variance (ANOVA) and the significance between means was explored using the post-hoc Tukey HSD test, at a significance value of 0.05 .

\section{Results and Discussion}

\subsection{Nutritional Profile}

Table 1 summarizes the results on the seasonal variation of the nutritional profile of sawgrass biomass. As expected, the nutritional profile of sawgrass varied among seasons. Dry matter (DM) was higher in summer $\left(586 \mathrm{~g} \mathrm{~kg}^{-1}\right)$ and autumn $\left(560 \mathrm{~g} \mathrm{~kg}^{-1}\right)$ than in spring $\left(449 \mathrm{~g} \mathrm{~kg}^{-1}\right)$ and winter $\left(469 \mathrm{~g} \mathrm{~kg}^{-1}\right)$. The ash level peaked in autumn $\left(82 \mathrm{~g} \mathrm{~kg}^{-1}\right.$ $\mathrm{DM})$ and was minimum in summer $\left(49 \mathrm{~g} \mathrm{~kg}^{-1}\right)$, during the heading and seed ripe stage, similar to other grasses and sedges [32]. The ash content of sawgrass was lower than those reported for other salt-tolerant plants [5,33], such as species belonging to Chenopodiaceae, Juncaceae, Tamaricaceae, and Zygophyllaceae genera (ranging from $122-403 \mathrm{~g} \mathrm{~kg}^{-1}$ ). This is probably due to different approaches in use by grasses for osmotic adjustment to cope with salinity levels, e.g., water loss vs. ion accumulation [34].

Table 1. Seasonal effects on the nutritional value, in vitro digestibility, and mineral content of aerial parts of sawgrass (C. mariscus) biomass.

\begin{tabular}{|c|c|c|c|c|}
\hline & Spring & Summer & Autumn & Winter \\
\hline \multicolumn{5}{|l|}{ Nutritional profile $\left(\mathrm{g} \mathrm{kg}^{-1}\right.$} \\
\hline DM & 449 & 586 & 559 & 469 \\
\hline Ash & 71.7 & 49.4 & 82.9 & 75.1 \\
\hline $\mathrm{CP}$ & 87.3 & 51.8 & 54.5 & 57.8 \\
\hline TL & 53.3 & 48.9 & 52.9 & 51.1 \\
\hline NDF & 596 & 690 & 628 & 613 \\
\hline $\mathrm{ADF}$ & 330 & 418 & 380 & 363 \\
\hline ADL & 8 & 24 & 8 & 5 \\
\hline Cellulose & 322 & 393 & 372 & 358 \\
\hline Hemicellulose & 266 & 272 & 248 & 250 \\
\hline IVOMD $\left(\mathrm{g} \mathrm{kg}^{-1} \mathrm{OM}\right)$ & 317 & 172 & 243 & 255 \\
\hline Mineral content & & & & \\
\hline \multicolumn{5}{|c|}{ Macro-minerals ( $\left.\mathrm{g} \mathrm{kg}^{-1} \mathrm{DM}\right)$} \\
\hline $\mathrm{Ca}$ & 6.9 & 1.6 & 3.8 & 3.8 \\
\hline K & 4.4 & 3.9 & 2.3 & 2.4 \\
\hline $\mathrm{Mg}$ & 0.8 & 0.7 & 0.7 & 0.7 \\
\hline $\mathrm{Na}$ & 8.1 & 1.43 & 5.7 & 4.9 \\
\hline \multicolumn{5}{|c|}{ Trace minerals (mg kg $\left.{ }^{-1} \mathrm{DM}\right)$} \\
\hline $\mathrm{Fe}$ & 186 & 214 & 42.8 & 32.3 \\
\hline $\mathrm{Zn}$ & 15.2 & 21.1 & 20.4 & 24.7 \\
\hline $\mathrm{Cu}$ & 3.9 & 7.7 & 5.9 & 9.6 \\
\hline $\mathrm{Mn}$ & 40.7 & 20.0 & 29.1 & 49.0 \\
\hline $\mathrm{Cr}$ & 4.3 & 13.0 & 1.7 & 2.3 \\
\hline
\end{tabular}

DM: Dry matter; OM: Organic matter; CP: Crude protein; TL: Total lipids; NDF: Neutral detergent fiber; ADF Acid detergent fiber; ADL: Acid detergent lignin; IVOMD: In vitro organic matter digestibility; Ca: Calcium; K: Potassium; Mg: Magnesium; Na: Sodium; Fe: Iron; Zn: Zinc; Mn: Manganese; Cr: Chromium.

Crude protein $(\mathrm{CP})$ is often used as a major indicator of forage quality as is correlated with vegetative vigor [35]. Sawgrass aerial organs present a very low $\mathrm{CP}$ during all seasons (51-57 $\left.\mathrm{g} \mathrm{kg}^{-1} \mathrm{DM}\right)$ except in Spring when it is slightly higher $\left(87 \mathrm{~g} \mathrm{~kg}^{-1} \mathrm{DM}\right)$. Its CP content is similar to that observed for other salt-tolerant species studied as potential forages for ruminants, such as Halocnemum strobilaceum (Pall.) M.Bieb. (67 $\left.\mathrm{g} \mathrm{kg}^{-1} \mathrm{DM}\right)$, Juncus acutus L. (71 $\left.\mathrm{g} \mathrm{kg}^{-1} \mathrm{DM}\right)$, Salsola tetandra Forssk. ( $\left.63 \mathrm{~g} \mathrm{~kg}^{-1} \mathrm{DM}\right)$, and Zygophyllum album L. (78 $\left.\mathrm{g} \mathrm{kg}^{-1} \mathrm{DM}\right)$ [5] but lower than Cynodon dactylon (Bermuda grass; $98 \mathrm{~g} \mathrm{~kg}^{-1}$ ) [36], Atriplex amnicola (161 $\left.\mathrm{g} \mathrm{kg}^{-1} \mathrm{DM}\right)$ [37] or A. halimus $\left(167 \mathrm{~g} \mathrm{~kg}^{-1} \mathrm{DM}\right)$ [38]. Still, it is a low 
value when compared with Mediterranean rainfed pastures ( 73 up to $500 \mathrm{~g} \mathrm{~kg}^{-1} \mathrm{DM}$ ) in which the lowest $\mathrm{CP}$ observed in summer are comparable to the highest $\mathrm{CP}$ of sawgrass observed in Spring [39]. In agreement, sawgrass CP contents are similar to those observed for some sedge species with a low forage potential such as Carex vulinoidea (58-110 g kg-1 $\mathrm{DM})$ and C. aenea (59-75 $\left.\mathrm{g} \mathrm{kg}^{-1} \mathrm{DM}\right)[40]$.

High levels of fiber, including NDF (596-690 $\left.\mathrm{g} \mathrm{kg}^{-1}\right)$, ADF (330-418 $\left.\mathrm{g} \mathrm{kg}^{-1}\right)$, and ADL (5-24 $\mathrm{g} \mathrm{kg}^{-1}$ ) were observed for all seasons, with a peak in summer, probably as a result of the reproductive stage. Catling et al. (1994) observed a significant increase throughout summer in the ADF contents of Carex sedge species, coupled with a decline in digestibility and CP [40]. However, these changes can be a result of a combination of different factors, such as plant maturity, meteorological changes or harvest collection [40]. Aerial parts are also characterized by quite low IVOMD, which varied from $171 \mathrm{~g} \mathrm{~kg}^{-1}$ $\mathrm{OM}$ in summer to $317 \mathrm{~g} \mathrm{~kg}^{-1} \mathrm{OM}$ in spring. Fiber is often the bulk of ruminant's diets and its digestibility is determinant of the forage's quality. The concentration and type of structural polysaccharides, as cellulose and hemicellulose, and the degree of its lignification determines its digestibility and hence its usefulness of the forage for supporting ruminant production [41]. In this work, the very low IVOMD is correlated to the high NDF (Pearson's correlation, $\mathrm{r}=-0.958 ; p<0.05)$ and $\mathrm{ADF}(\mathrm{r}=-0.994 ; p<0.05)$ results. A negative correlation between organic matter digestibility with cell wall fractions, particularly NDF, is well recognized [42]. The fiber and digestibility values of sawgrass are similar to that of other Carex sedge species (ADF, 276-409 $\mathrm{g} \mathrm{kg}^{-1}$; digestibility, 203-337 g kg-1 $\mathrm{OM})$ [40]. Still, the IVOMD result obtained in summer (172 $\left.\mathrm{g} \mathrm{kg}^{-1} \mathrm{OM}\right)$ emphasizes its poor digestibility, since it is even lower than the 77 Carex species studied [40]. On the other hand, a high content of secondary metabolites, such as condensed tannins, might also limit digestibility. Despite the fact that high tannin contents $(>5-6 \%)$ may impair feed intake, animal productivity, and digestion, moderate amounts (2-5\%) exert beneficial effects such as improving protein and ruminal metabolism and reducing methane emissions, consequently increasing the overall nutritive value $[43,44]$. The CTC in C. mariscus biomass was estimated around $2-4 \%$ DM (data not shown), and therefore, its impact on digestibility is expected to be minor. Nevertheless, in addition to the concentration, the chemical structure of tannins present as well as the diet composition will also be a determinant of its benefits in ruminant nutrition and health [45].

The mineral composition of sawgrass is presented in Table 1. All macro- and trace minerals were within the maximum tolerable levels, reported by the National Research Council, for ruminants [46]. Minerals have a key role in structural, physiological, and regulatory processes, and thus mineral deficiency may have a significant negative impact in animal health and performance [47]. The seasonal distribution of macro- and trace mineral contents had dispersed patterns throughout the seasons: high amounts of $\mathrm{Na}$ and Ca were noted in spring; $\mathrm{K}$ and Fe were higher in spring/summer; $\mathrm{Zn}$ only decreased in spring; $\mathrm{Cr}$ was particularly higher in summer; $\mathrm{Mn}$ increased in spring/winter; while $\mathrm{Mg}$ was stable throughout the seasons. The salt (sodium chloride) content is one of the major drawbacks of using salt-tolerant plants as forages for livestock [48]. In the case of sawgrass, the Na concentration increased in spring $\left(8.1 \mathrm{~g} \mathrm{~kg}^{-1} \mathrm{DM}\right)$ and was lowest in summer $\left(1.4 \mathrm{~g} \mathrm{~kg}^{-1} \mathrm{DM}\right)$. The negative effects of high Na dietary levels on feed intake and animal performance are negligible if water is freely available. Moreover, forages are often deficitary in $\mathrm{Na}$ and salt supplementation of ruminants is usually needed [49]. Potassium (K) values peaked in spring $\left(4.4 \mathrm{~g} \mathrm{~kg}^{-1} \mathrm{DM}\right)$ and decreased in the other seasons. The magnesium $(\mathrm{Mg})$ content did not differ among seasons $(p>0.05)$ but the calcium $(\mathrm{Ca})$ levels were lower in summer $\left(1.6 \mathrm{~g} \mathrm{~kg}^{-1} \mathrm{DM}\right)$ and peaked in spring $\left(6.9 \mathrm{~g} \mathrm{~kg}^{-1} \mathrm{DM}\right)$. Having in mind the macro-mineral concentration requirements for ruminants [50], sawgrass aerial organs are able to supply dietary levels of $\mathrm{Ca}$ and $\mathrm{Na}$, while low levels of $\mathrm{Mg}$ and $\mathrm{K}$ are observed. Regarding trace minerals, sawgrass biomass has adequate levels of iron $(\mathrm{Fe})$, the main component of hemoglobin and myoglobin, particularly in summer and spring periods (186-214 $\left.\mathrm{mg} \mathrm{kg}^{-1} \mathrm{DM}\right)$. Along with other elements, zinc ( $\left.\mathrm{Zn}\right)$, manganese $(\mathrm{Mn})$, and copper 
(Cu) participate in antioxidant defense mechanisms and thus, a balanced supply of these elements is important during ruminant production [51]. Mn levels were higher in summer and winter seasons (40.7-49.0 mg kg $\left.{ }^{-1} \mathrm{DM}\right)$, while the $\mathrm{Zn}$ and $\mathrm{Cu}$ contents increased in winter ( $\mathrm{Zn}, 24.7 \mathrm{mg} \mathrm{kg}{ }^{-1} \mathrm{DM} ; \mathrm{Cu}, 9.6 \mathrm{~g} \mathrm{~kg}^{-1}$ ) and dropped in spring (Zn, $15.2 \mathrm{mg} \mathrm{kg}^{-1}$ $\left.\mathrm{DM} ; \mathrm{Cu}, 3.9 \mathrm{~g} \mathrm{~kg}^{-1}\right)$. Although $\mathrm{Zn}$ levels are low, in comparison to other highly salt-tolerant plants [51], Mn and $\mathrm{Cu}$ results present similar contents. Overall, Fe and Mn concentrations of sawgrass are within the threshold of dietary levels in forages for ruminants [52]. It is important to take into consideration that the concentration of these elements is dependent on soil and plant related factors $[47,53,54]$, and consequently may vary greatly.

Altogether, the results on the nutritional profile and mineral content of sawgrass biomass indicate that it is a low-quality roughage with limited interest as a nutrient supplier for ruminants. This is in agreement with other sedge species (Cyperaceae) which have been pointed out as used for animal forage and grazed by ruminants, but the majority are reportedly of poor-quality [40,55].

A comparison of our results with others is hampered by the lack of published data concerning $C$. mariscus, particularly its nutritional value and mineral content. Only one study analyzed the nutlets, rhizomes, and culms of C. mariscus collected in South Africa [56]. Sievers (2015) showed that the nutlets are not a rich source of protein $\left(30 \mathrm{~g} \mathrm{~kg}^{-1}\right)$ or fat $\left(3 \mathrm{~g} \mathrm{~kg}^{-1}\right)$ but have a high content of carbohydrates $\left(490 \mathrm{~g} \mathrm{~kg}^{-1} \mathrm{DM}\right)$, however digestible and undigestible fiber contents were not addressed [56].

\subsection{Phenolic Content of the Extracts}

Phenolic compounds are a major group of plant secondary metabolites with a panoply of well documented bioactive properties including antioxidant, anti-inflammatory, and antimicrobial. The use of phenolics or phenolic-rich plants (particularly in tannins and flavonoids) as natural alternatives to improve animal nutrition, health, and productivity has gained the interest of the scientific community in the last decades [11-14]. Therefore, the identification of species which are rich sources of phenolic compounds and its characterization meets the current research agenda on ruminant production.

Figure 1 represents the seasonal variations of the total phenolic content of sawgrass extracts, determined by spectrophotometric methods. A high TPC was noted for all samples ( $>20 \mathrm{mg} \mathrm{g}^{-1}$ extract) [44] and it was significantly increased in summer and autumn samples (112.32-104.3 $\mathrm{mg} \mathrm{GAE} \mathrm{g}^{-1}$ extract) in contrast to spring (88.6 $\mathrm{mg} \mathrm{GAE} \mathrm{g}^{-1}$ extract). Similarly, CTC was lower in spring (115.1 $\mathrm{mg} \mathrm{CE} \mathrm{g}^{-1}$ extract) but remained stable in the other seasons (153.1-169.6 mg CE g ${ }^{-1}$ extract). No significant differences were recorded for TFC, throughout the seasons (18.5-20.2 $\mathrm{mg} \mathrm{QE} \mathrm{g}^{-1}$ extract).

Seasonal variations on the TPC and CT contents of $C$. mariscus were expected, having in mind that the phenolic content of plant tissues is influenced by the climate, geography, type of organ, nutrient-related stress, and salinity, as well as laboratory drying and extraction methodologies [54-57]. Thus, the increased levels noted for summer and autumn periods could be a result of the plant response to counteract the environmental challenges during these seasons, e.g., drought and high UV exposure. Moreover, phenolics biosynthesis is also known to be enhanced during metal stress, aiming for the protection of the plant from oxidative stress [58], and, therefore, the levels of $\mathrm{Zn}, \mathrm{Cu}$, and $\mathrm{Cr}$ during summer and/or autumn seasons may have contributed to this augmented phenolic concentration. On the other hand, during these periods, inflorescences were collected along with leaves, and thus, the possibility of organ-related variations should not be excluded. 


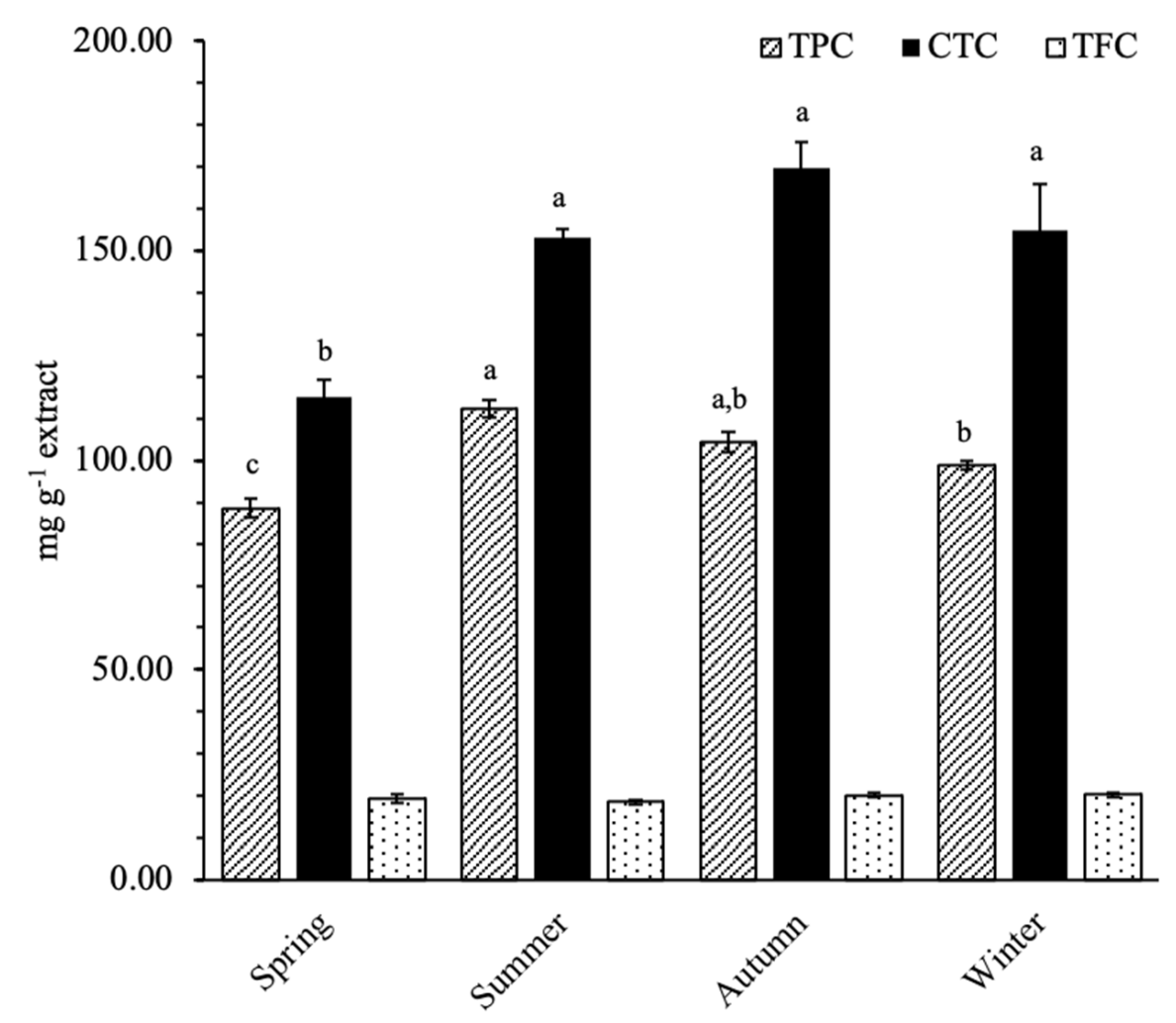

Figure 1. Seasonal variation of the total phenolic levels of sawgrass (C. mariscus) aqueous acetone extracts. TPC: Total phenolic content, expressed as $\mathrm{mg}$ gallic acid equivalents $\mathrm{g}^{-1}$ extract $\left(\mathrm{mg} \mathrm{GAE} \mathrm{g}^{-1}\right.$, DW); CTC: Condensed tannins content, expressed as $\mathrm{mg}$ catechin equivalents $\mathrm{g}^{-1}$ extract $\left(\mathrm{mg} \mathrm{CE} \mathrm{g}^{-1}\right.$, DW); TFC: Total flavonoid content, expressed as mg quercetin equivalents $\mathrm{g}^{-1}$ extract (mg QE g $\left.{ }^{-1}, \mathrm{DW}\right)$. Values are expressed as mean with standard deviation of the mean represented $(n=12)$. Different letters superscript represent significant differences among seasons, for each assay ( $p<0.05$; Tukey HSD).

Lopes et al. presented higher TPC (254 $\mathrm{mg} \mathrm{GAE}^{-1}$ extract) but lower TFC (13.8 mg RE eq. $\mathrm{g}^{-1}$ extract) and CTC values ( $38.7 \mathrm{mg} \mathrm{CE} \mathrm{g}^{-1}$ extract) [9]. These differences may be explained by the different extraction methodologies applied by those authors, i.e., $70 \%$ acetone extracts, but also environmental and organ-related factors, i.e., leaves collected in June 2013 whilst aerial parts collected amongst different seasons. The high CTC content of sawgrass extracts is particularly interesting: despite the fact that it might contribute to its very low digestibility it also holds potential applications. Tannins have been perceived, for a long time, as anti-nutritional metabolites, mainly due to its negative effects on animal feed intake and nutrient digestibility [59]. However, there is a body of evidence showing that tannins, in the right dosage, also have important positive effects on animals, including the decrease of methane production, control of gastrointestinal parasites, preventing bloat, and improving meat fatty acid composition $[6,11,15,45,59]$.

Aiming to identify and quantify individual phenolics, samples were subjected to HPLC-DAD analysis, as summarized in Table 2 and chromatograms represented in Figure 2. In agreement with our previous spectrophotometric results, the summer and autumn samples exhibit increased levels of phenolics (Figure 2). Eleven compounds were identified and quantified, specifically five flavonoids (catechin, epicatechin, naringenin-7-glucoside, luteolin-7-O-glucoside, and quercetin), and six phenolic acids, namely gallic, caffeic, chlorogenic, syringic, ferulic, and salicylic acids (Table 2). These compounds are, to the best of our knowledge, herein firstly identified and quantified in sawgrass. 
Table 2. HPLC-diode array detection (HPLC-DAD) identification and quantification ( $\mathrm{mg} \mathrm{g}^{-1}$ extract) of the phenolic compounds of sawgrass (C. mariscus) extracts, for the different seasons. Peaks are numbered according to its retention time, in ascending order.

\begin{tabular}{|c|c|c|c|c|c|c|c|}
\hline Phenolic Group & RT (min) & Compound & Peak & Spring & Summer & Autumn & Winter \\
\hline \multicolumn{8}{|l|}{ Flavonoids } \\
\hline Flavanone & 19.3 & Naringenin-7-O-glucoside & 9 & $<0.01$ & 0.01 & 0.03 & 0.01 \\
\hline Flavone & 20.4 & Luteolin-7-O-glucoside & 10 & 0.16 & 0.46 & 0.98 & 0.24 \\
\hline \multirow[t]{3}{*}{ Flavanols } & 26.2 & Quercetin & 11 & 0.03 & 0.03 & 0.03 & 0.01 \\
\hline & 9.5 & Catechin hydrate & 2 & - & 0.77 & 0.76 & 0.10 \\
\hline & 13.9 & Epicatechin & 6 & 0.42 & 0.88 & 1.49 & 1.06 \\
\hline \multirow{6}{*}{$\begin{array}{c}\text { Phenolic acids } \\
\text { Hydroxybenzoic acids }\end{array}$} & & & & & & & \\
\hline & 2.6 & Gallic acid & 1 & $<0.01$ & 0.01 & $<0.01$ & $<0.01$ \\
\hline & 8.5 & p-Hidroxybenzoic acid & - & - & $<0.01$ & $<0.01$ & - \\
\hline & 13.5 & Syringic Acid & 5 & 0.19 & 0.35 & 0.73 & 0.35 \\
\hline & 17.8 & Salicylic Acid & 8 & 2.11 & 1.64 & 2.92 & 2.09 \\
\hline & 22.3 & Ellagic Acid & - & $<0.01$ & - & - & - \\
\hline \multirow[t]{4}{*}{ Hydroxycinnamic acid } & 12.6 & Cafeic Acid & 3 & 0.67 & 0.73 & 0.76 & 0.70 \\
\hline & 15.8 & Coumaric Acid & - & $<0.01$ & $<0.01$ & $<0.01$ & $<0.01$ \\
\hline & 16.9 & Ferulic Acid & 7 & 1.88 & 1.38 & 2.40 & 1.58 \\
\hline & 13.1 & Chlorogenic Acid & 4 & 3.03 & 2.96 & 4.45 & 2.29 \\
\hline \multirow[t]{2}{*}{ Other } & 10.3 & 4-Hydroxybenzaldehyde & - & $<0.01$ & $<0.01$ & $<0.01$ & - \\
\hline & & $\sum$ Phenolics & & 8.49 & 9.22 & 14.55 & 8.43 \\
\hline
\end{tabular}

RT: Retention time; -: Not detected.
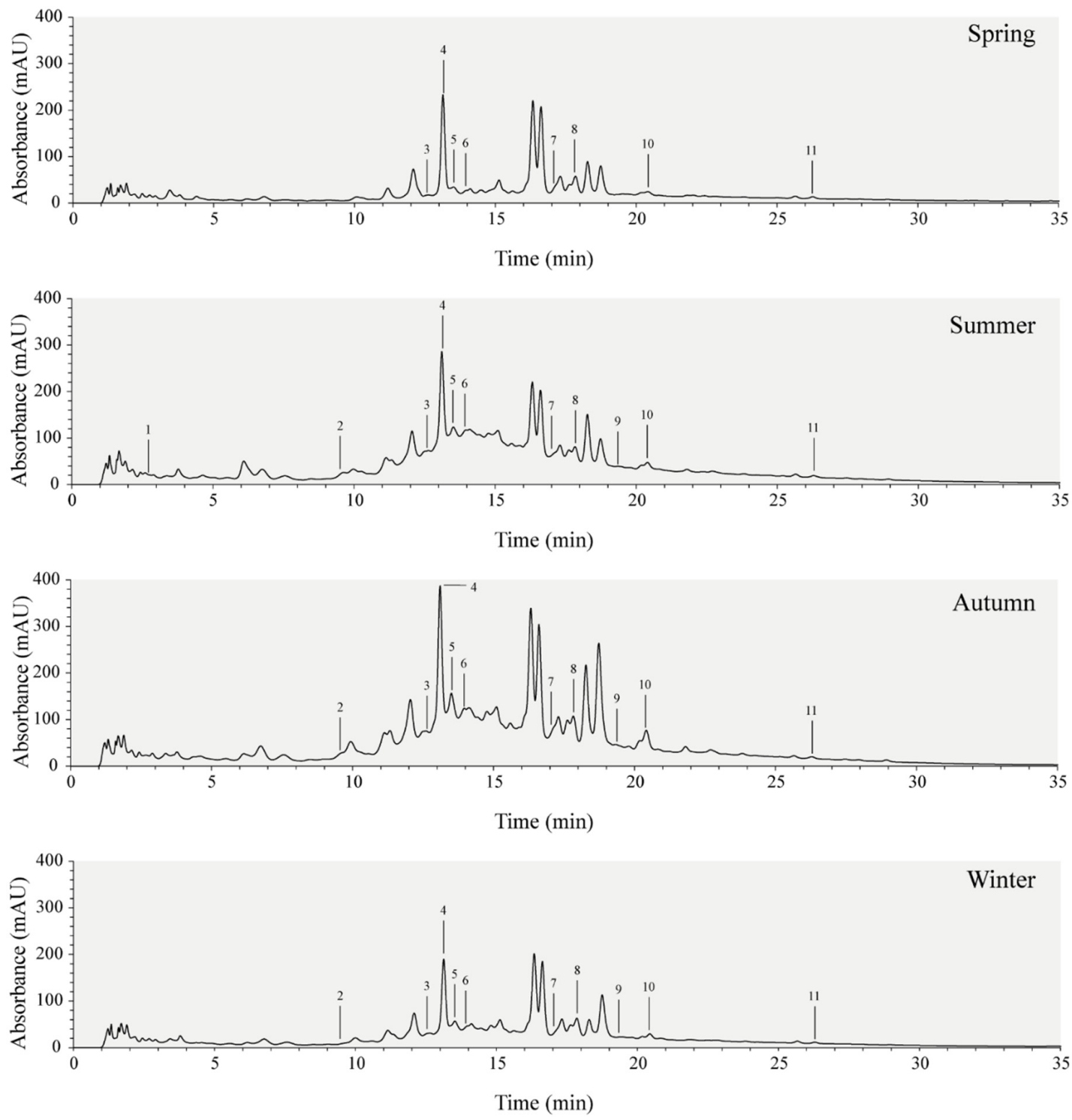

Figure 2. HPLC-DAD chromatograms of sawgrass (C. mariscus) acetone water extracts throughout the seasons. 
Phenolic compounds play a major role in plant defense mechanisms against biotic and abiotic stressors and thereof, it was anticipated that their concentration would vary accordingly.

Chlorogenic acid (CGA) was the most abundant compound in all samples with concentrations ranging from 2.29 up to $4.45 \mathrm{mg} \mathrm{g}^{-1}$ extract, marking the lowest value in winter. CGA is a strong antioxidant compound produced under environmental stresses such as boron and nitrogen deficits and intense UV radiation [60-62]. In agreement, Meot-Duros and Magné (2009), found that Crithmum maritimum L. plants living in sand hills, a stressful habitat, had increased amounts of CGA than those living below cliffs [63]. In this study, the variability of CGA in sawgrass extracts may be linked to the increased oxidative stresses developed in response to the higher temperatures, UV radiation, and lower precipitation values in summer and autumn.

Other phenolic acids quantified are salicylic (1.64-2.92 $\mathrm{mg} \mathrm{g}^{-1}$ extract), ferulic acid (1.38-2.40 $\mathrm{mg} \mathrm{g}^{-1}$ extract), and syringic acid (0.19-0.73 $\left.\mathrm{mg} \mathrm{g}^{-1}\right)$, all present in higher concentrations in the autumn sample. Similarly, to CGA, salicylic acid, an important regulator of plant growth, is also involved in the induction of defense responses and tolerance to drought [64], heavy metal tolerance [65], salinity [66], and heat [67]. On the other hand, syringic and ferulic acids are important contributors to the structure integrity of lignin, providing overall rigidity and strength to the plant cell wall $[68,69]$. Thus, the accumulation of these compounds during the dry seasons can also be linked to an increase in cell wall lignification, in response to abiotic stressful conditions [70]. In addition to their physiological role, these phenolic acids have documented bioactivities of pharmacological importance such as antioxidant, anti-inflammatory, hepatoprotective, cardioprotective, and antimicrobial $[69,71,72]$.

Besides phenolic acids, plants inhabiting the harsh Mediterranean environmental settings, particularly excessive sunlight and drought/salinity, also accumulate higher amounts of UV-absorbing and antioxidant flavonoids and its glycosides and other polyphenols, which play a role in the photoprotection of the plant [73]. In accordance, in this work, the flavonoids naringenin-7-glucoside, luteolin-7-O-glucoside, catechin, epicatechin, and quercetin were mostly increased in seasons with higher light irradiance and UV exposure. Luteolin-7-O-glucoside concentration was significantly enhanced in bell pepper leaves after UV-B exposure, probably due to its high antioxidant capacity needed to quench the reactive oxygen species (ROS) produced [74]. In addition to antioxidant and anti-inflammatory activities [75], luteolin-7-O-glucoside also exhibits in vitro methane and ammonia mitigating properties [76], and quercetin, luteolin, and naringenin display in vitro anthelmintic properties against gastrointestinal parasites of small ruminants [77].

In total, a higher amount of identified compounds was quantified in autumn (14.55 $\mathrm{mg} \mathrm{g}^{-1}$ extract) compared to the other seasons (8.43-9.22 $\mathrm{mg} \mathrm{g}^{-1}$ extract). Nonetheless, due to the complexity of the extract mixtures, it is worth mentioning that a large number of compounds remain to be identified, including two major metabolites (e.g., retention time between 16-17 min; Figure 2), which is already being pursued by additional hyphenated methods.

\subsection{Bioactive Properties}

As in other animals, the oxidative stress in ruminants is mainly associated with metabolic and inflammatory disorders, environmental factors (e.g., heat stress), and dietary imbalances [78], and can significantly impair important physiological and immunological functionalities, compromising animal welfare and performance [79,80]. Former reviews point out to the beneficial effects of using antioxidant supplementation, particularly for improving the animal general antioxidant status in reproductive-related events (e.g., lactation, fertility) [80,81], inflammatory processes (e.g., mastitis, parasitic infections) [82,83], and on enhancing the quality of derived products (meat, milk) [79]. Additionally, there is an increasing interest in using bioactive plants, rich in antioxidants, such as phenolics, for the latter purpose $[10,78,84]$. 
Seasonal variations on the antioxidant capacity of the extracts are represented in Figure 3. All the samples were effective on scavenging $\mathrm{DPPH}^{\bullet}$ and $\mathrm{ABTS}^{\bullet+}$ radicals $\left(\mathrm{IC}_{50}<0.30 \mathrm{mg} \mathrm{mL}^{-1}\right)$. While no statistical differences for the activity towards $\mathrm{DPPH}^{\bullet}$ were observed, the ability to scavenge $\mathrm{ABTS}^{\bullet+}$ was higher in summer $\left(\mathrm{IC}_{50}=0.12 \mathrm{mg} \mathrm{mL}^{-1}\right)$, with an $\mathrm{IC}_{50}$ value comparable to the positive control, BHT $\left(\mathrm{IC}_{50}=0.10 \mathrm{mg} \mathrm{mL}^{-1}\right)$. Similarly, the summer sample was significantly more efficient on scavenging the $\mathrm{O}_{2}{ }^{-}$'radical $\left(\mathrm{IC}_{50}=0.79 \mathrm{mg} \mathrm{mL}^{-1}\right)$ and on chelating copper $\left(\mathrm{CCA} ; \mathrm{IC}_{50}=2.45 \mathrm{mg} \mathrm{mL}^{-1}\right)$. In contrast, the FRAP activity remained unchanged throughout the seasons $\left(\mathrm{IC}_{50}=0.18-0.27 \mathrm{mg} \mathrm{mL}^{-1}\right.$ ) and none of the samples was able to chelate iron at the maximum concentration tested $\left(10 \mathrm{mg} \mathrm{mL}^{-1}\right)$. The variability amongst the antioxidant activity results obtained, emphasize the importance of using different in vitro methodological approaches [85] due to the dissimilarities among the test systems in this study. Lopes et al. reported an $\mathrm{IC}_{50}$ value of $0.23 \mathrm{mg} \mathrm{mL}^{-1}$ towards the $\mathrm{DPPH}^{\bullet}$ radical, for a $70 \%$ acetone extract of leaves of the same species, similar to those obtained in this study $\left(0.24-0.30 \mathrm{mg} \mathrm{mL}^{-1}\right)$ [9]. However, the $\mathrm{IC}_{50}$ value presented against the $\mathrm{ABTS}^{\bullet+}$ radical $\left(0.32 \mathrm{mg} \mathrm{mL}^{-1}\right)$ was slightly higher in comparison to our results, especially with the summer sample $\left(0.12 \mathrm{mg} \mathrm{mL}^{-1}\right)$. As previously mentioned, besides environmental and methodological variations, the collection of inflorescences during the summer period could have contributed to this difference. Having in mind that a correlation between TPC and antioxidant activity has been previously reported in the literature $[85,86]$, the generally greater antioxidant activity noted in summer can most probably be attributed to the augmented phenolic content noted in this period. In fact, Meot-Duros and Magné (2009) found a linear correlation not only between DPPH and ABTS anti-radical activity of $C$. maritimum leaves and total phenolics, but particularly with CGA [63]. Furthermore, anti-radical and total phenols were increased in summer in detriment to the winter samples [63]. Despite the fact that several phenolics identified in this study have described the antioxidant activity in literature, CGA was present in higher amounts, and thus is most probably significantly contributing to the total antioxidant capacity observed, particularly in summer. Nevertheless, one should not reject the possibility of other phytochemicals to be present that may also contribute to this activity and/or of synergistic effects between these metabolites.

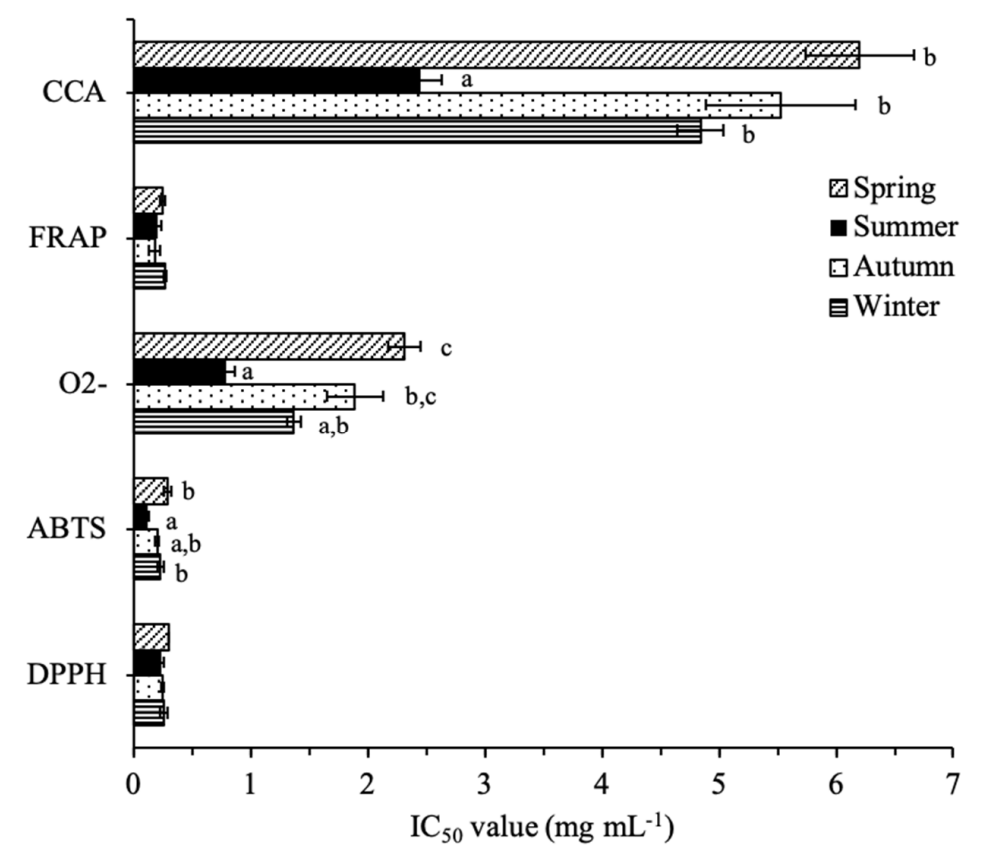

Figure 3. Seasonal variation of the antioxidant capacity of sawgrass (C. mariscus) extracts. Values are expressed as $\mathrm{IC}_{50}$ with the standard deviation represented $(\mathrm{n}=3)$. Different letters superscript correspond to significant differences between seasons, for each assay ( $p<0.05$; Tukey HSD). CCA: Copper chelating activity; FRAP: Ferric reduction antioxidant power. 
Biswas (2016) highlights that oxidative stress inflammation are closely related and associated events and, therefore, the identification of bioactive agents targeting both processes is relevant [87]. NO plays a pivotal role in the mediation of immune response and inflammation, and high levels are detected in several ruminant inflammatory processes, such as mastitis and reproductive disorders, in which oxidative stress is also involved [82]. In this work, and despite the fact that no statistical differences were recorded amongst the seasons, the extracts were able to reduce NO production by $30 \%$, in comparison to the control cells (Figure 4). Among the phenolic compounds previously identified in sawgrass extracts, the majority are well recognized for its anti-inflammatory effects, such as syringic acid [69], ferulic acid [72], and luteolin-7-O-glucoside [75]. The chlorogenic acid inhibits NO production, COX-2 and iNOS expression, pro-inflammatory cytokines production, and nuclear translocation of NF-kB, with pronounced effects at $20 \mu \mathrm{M}$ [88]. Additionally, anti-inflammatory phenolic compounds may act together: For example, quercetin and catechin exhibit synergistic anti-inflammatory effects in LPS-stimulated macrophage RAW 264.7 cells by decreasing NO, TNF- $\alpha$, IL-1 $\beta$, iNOS, COX-2, inhibiting NF- $\kappa$ B, as well as the activation of LR4-MyD88-mediated NF- $\mathrm{B}$ and the expression of mitogen-activated protein kinases [89].

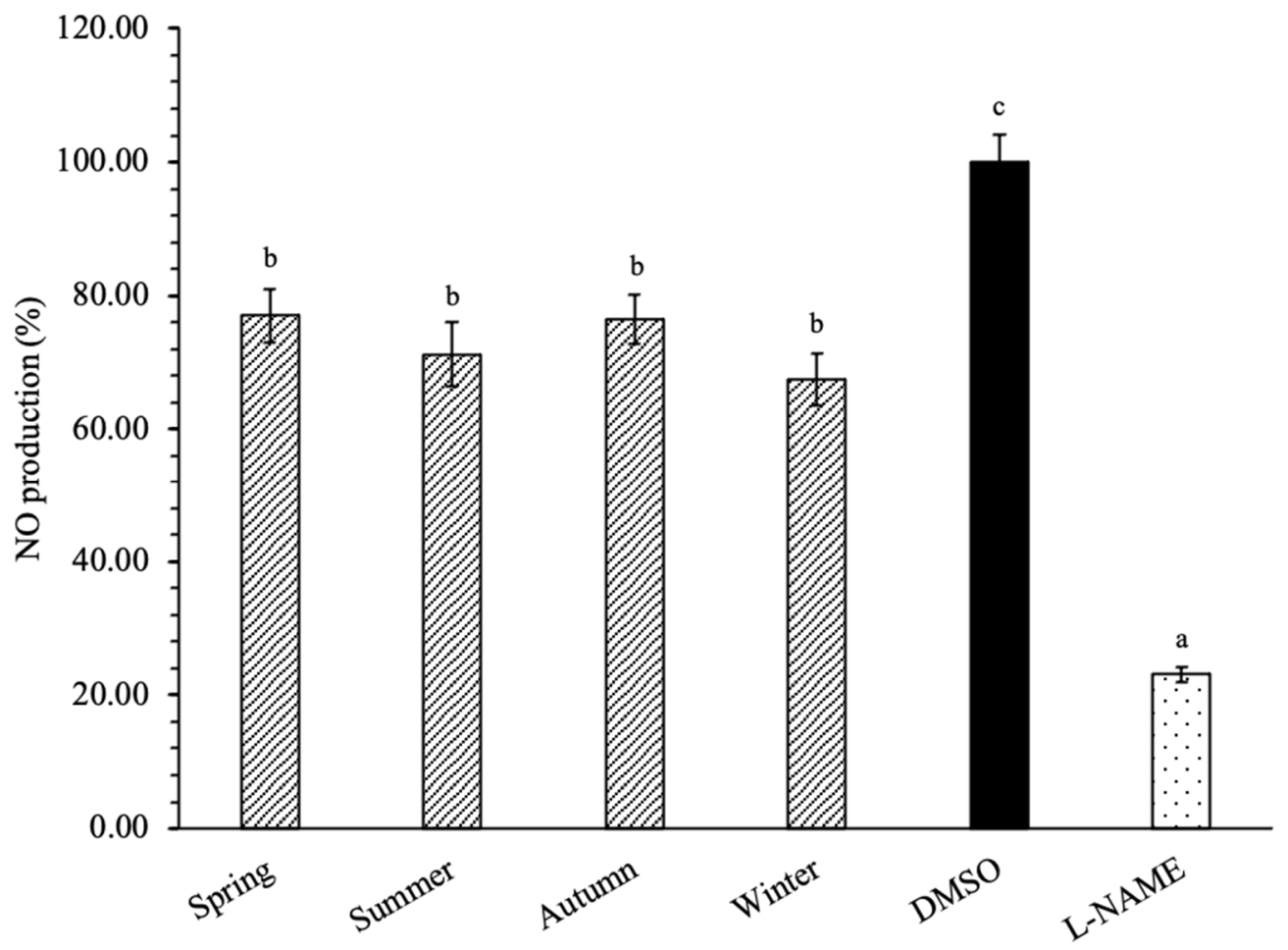

Figure 4. Season effects on nitric oxide (NO) production by lipopolysaccharide (LPS)-stimulated RAW 264.7 macrophages (\%) of sawgrass (C. mariscus) extracts, applied at $100 \mu \mathrm{g} \mathrm{mL}^{-1}(\mathrm{n}=12)$. L-NAME (L-NG-Nitro arginine methyl ester) was used as the positive control $\left(100 \mu \mathrm{g} \mathrm{mL}^{-1}\right)$. Different letters correspond to significant differences between the samples $(p<0.05)$.

Although in this study the extracts were tested at a maximum concentration of $100 \mu \mathrm{g} \mathrm{mL}^{-1}$, further investigations including higher concentrations may unveil increased anti-inflammatory properties, as long as no cytotoxic effects remain.

\section{Conclusions}

Sawgrass biomass has a chemical composition and mineral content similar to that of other roughage resources characterized by low crude protein, high indigestible fiber contents, very low in vitro digestibility, and therefore has limited interest as a nutrient supplier for ruminants. On the other hand, acetone water extracts from its biomass confirmed this 
species as a rich source of antioxidant and anti-inflammatory phenolic compounds particularly in summer and autumn samples, that can be valuable assets in integrated control strategies on the management of oxidative stress and inflammatory related disorders affecting ruminant's health, productivity, and performance. Further studies should be pursued to deepen the knowledge on its potential veterinary phytotherapeutic applications.

Author Contributions: Funding acquisition, R.J.B.B. and L.C.; investigation, M.O., M.J.R., N.R.N., J.M.F.N., and R.J.B.B.; methodology, L.C.; supervision, R.J.B.B. and L.C.; writing—original draft, M.O.; writing-review and editing, R.J.B.B. and L.C. All authors have read and agreed to the published version of the manuscript.

Funding: This study received Portuguese national funds from FCT-Foundation for Science and Technology (GreenVet-ALG-01-0145-FEDER-028876 and UIDB/04326/2020 projects). M.O. acknowledges FCT for the PhD grant SFRH/BD/116604/2016. L.C. was supported by the FCT Investigator Programme (CEECIND/00425/2017).

Acknowledgments: The authors acknowledge Tamára Santos and Vera Gomes (CCMAR) for technical assistance during crude protein and mineral analysis.

Conflicts of Interest: The authors declare no conflict of interests.

\section{References}

1. Giorgi, F; Bi, X. Updated regional precipitation and temperature changes for the 21st century from ensembles of recent AOGCM simulations. Geophys. Res. Lett. 2005, 32, L21715. [CrossRef]

2. Alo, C.A.; Anagnostou, E.N. A sensitivity study of the impact of dynamic vegetation on simulated future climate change over Southern Europe and the Mediterranean. Int. J. Climatol. 2017, 37, 2037-2050. [CrossRef]

3. Lionello, P.; Malanotte-Rizzoli, P.; Boscolo, R.; Alpert, P.; Artale, V.; Li, L.; Luterbacher, J.; May, W.; Trigo, R.; Tsimplis, M.; et al. The Mediterranean climate: An overview of the main characteristics and issues. In Mediterranean Climate Variability; Lionello, P., Malanotte-Rizzoli, P., Boscolo, R., Eds.; Elsevier: Amsterdam, The Netherlands, 2006.

4. Guerreiro, O.; Dentinho, M.T.P.; Moreira, O.C.; Guerra, A.R.; Ramos, P.A.B.; Bessa, R.J.B.; Duarte, M.F.; Jerónimo, E. Potential of Cistus ladanifer L.(rockrose) in small ruminant diets-Effect of season and plant age on chemical composition, in vitro digestibility and antioxidant activity. Grass Forage Sci. 2016, 71, 437-447. [CrossRef]

5. El Shaer, H.M. Halophytes and salt-tolerant plants as potential forage for ruminants in the Near East region. Small Rumin. Res. 2010, 91, 3-12. [CrossRef]

6. Vasta, V.; Luciano, G. The effects of dietary consumption of plants secondary compounds on small ruminants' products quality. Small Rumin. Res. 2011, 101, 150-159. [CrossRef]

7. Ksouri, R.; Ksouri, W.M.; Jallali, I.; Debez, A.; Magné, C.; Hiroko, I.; Abdelly, C. Medicinal halophytes: Potent source of health promoting biomolecules with medical, nutraceutical and food applications. Crit. Rev. Biotechnol. 2012, 32, 289-326. [CrossRef]

8. Oliveira, M.; Hoste, H.; Custódio, L. A systematic review on the ethnoveterinary uses of Mediterranean salt-tolerant plants: Exploring its potential use as fodder, nutraceuticals or phytotherapeutics in ruminant production. J. Ethnopharmacol. 2021, 267, 113464. [CrossRef]

9. Lopes, A.; Rodrigues, M.J.; Pereira, C.; Oliveira, M.; Barreira, L.; Varela, J.; Trampetti, F.; Custódio, L. Natural products from extreme marine environments: Searching for potential industrial uses within extremophile plants. Ind. Crop. Prod. 2016, 94, 299-307. [CrossRef]

10. Rochfort, S.; Parker, A.J.; Dunshea, F.R. Plant bioactives for ruminant health and productivity. Phytochemistry 2008, 69, $299-322$. [CrossRef]

11. Hoste, H.; Torres-Acosta, J.F.J; Sandoval-Castro, C.A.; Mueller-Harvey, I.; Sotiraki, S.; Louvandini, H.; Thamsborg, S.M.; Terril, T.H. Tannin containing legumes as a model for nutraceuticals against digestive parasites in livestock. Vet. Parasitol. 2015, 212, 5-17. [CrossRef] [PubMed]

12. Kalantar, M. The Importance of Flavonoids in Ruminant Nutrition. Arch. Anim. Husb. Dairy Sci. 2018, 1, 1-4.

13. Huang, Q.; Liu, X.; Zhao, G.; Ju, T.; Wang, Y. Potential and challenges of tannins as an alternative to in-feed antibiotics for farm animal production. Anim. Nutr. 2018, 4, 137-150. [CrossRef]

14. Olagaray, K.E.; Bradford, B.J. Plant flavonoids to improve productivity of ruminants-A review. Anim. Feed Sci. Technol. 2019, 251, 21-36. [CrossRef]

15. Guerreiro, O.; Alves, S.P.; Soldado, D.; Cachucho, L.; Almeida, J.M.; Francisco, A.; Santos-Silva, J.; Bessa, R.J.B.; Jerónimo, E. Inclusion of the aerial part and condensed tannin extract from Cistus ladanifer L. in lamb diets-Effects on growth performance, carcass and meat quality and fatty acid composition of intramuscular and subcutaneous fat. Meat Sci. 2020, 160, 107945. [CrossRef]

16. Gerdol, R.; Brancaleoni, L.; Lastrucci, L.; Nobili, G.; Pellizzari, M.; Ravaglioli, M.; Viciani, D. Wetland Plant Diversity in a Coastal Nature Reserve in Italy: Relationships with Salinization and Eutrophication and Implications for Nature Conservation. Estuaries Coast. 2018, 41, 2079-2091. [CrossRef] 
17. Abouzid, S. An active learning assignment to improve pharmacy students' knowledge of herbal medicine. J. Appl. Pharm. Sci. 2015, 5, 106-108. [CrossRef]

18. AbouZid, S.F.; Mohamed, A. Survey on medicinal plants and spices used in Beni-Sueif, Upper Egypt. J. Ethnobiol. Ethnomed. 2011, 7, 18. [CrossRef] [PubMed]

19. AOAC International. Official Methods of Analysis, 18th ed.; Method 942.05; AOAC International: Gaithersburg, MD, USA, 2005.

20. Bligh, E.G.; Dyer, W.J. A rapid method of total lipid extraction and purification. Can. J. Biochem. Physiol. 1959, 37, 911-917. [CrossRef] [PubMed]

21. Pereira, C.G.; Barreira, L.; Neng, N.R.; Nogueira, J.M.F.; Marques, C.; Santos, T.F.; Varela, J.; Custódio, L. Searching for new sources of innovative products for the food industry within halophyte aromatic plants: In vitro antioxidant activity and phenolic and mineral contents of infusions and decoctions of Crithmum maritimum L. Food Chem. Toxicol. 2017, 107, 581-589. [CrossRef]

22. Alexander, R.H.; McGowan, M. A filtration procedure for the in vitro determination of digestibility of herbage. Grass Forage Sci. 1961, 16, 275-276. [CrossRef]

23. Singleton, V.L.; Rossi, J.A. Colorimetry of total phenolics with phosphomolybdic-phosphotungstic acid reagents. Am. J. Enol. Vitic. 1965, 16, 144-158.

24. Rodrigues, M.J.; Soszynski, A.; Martins, A.; Rauter, A.P.; Neng, N.R.; Nogueira, J.M.F.; Varela, J.; Barreira, L.; Custódio, L. Unravelling the antioxidant potential and the phenolic composition of different anatomical organs of the marine halophyte Limonium algarvense. Ind. Crop. Prod. 2015, 77, 315-322. [CrossRef]

25. Quettier-Deleu, C.; Gressier, B.; Vasseur, J.; Dine, T.; Brunet, C.; Luyckx, M.; Cazin, M.; Cazin, J.C.; Bailleul, F.; Trotin, F. Phenolic compounds and antioxidant activities of buckwheat (Fagopyrum esculentum Moench) hulls and flour. J. Ethnopharmacol. 2000, 72, 35-42. [CrossRef]

26. Li, Y.G.; Tanner, G.; Larkin, P. The DMACA-HC1 Protocol and the threshold Proanthocyanidin Content for Bloat Safety in Forage Legumes. J. Sci. Food Agric. 1996, 70, 89-101. [CrossRef]

27. Rodrigues, M.J.; Neves, V.; Martins, A.; Rauter, A.P.; Neng, N.R.; Nogueira, J.M.F.; Varela, J.; Barreira, L.; Custódio, L. In vitro antioxidant and anti-inflammatory properties of Limonium algarvense flowers' infusions and decoctions: A comparison with green tea (Camellia sinensis). Food Chem. 2016, 200, 322-329. [CrossRef] [PubMed]

28. Megias, C.; Pastor-Cavada, E.; Torres-Fuentes, C.; Girón-Calle, J.; Alaiz, M.; Juan, R.; Pastor, J.; Vioque, J. Chelating, antioxidant and antiproliferative activity of Vicia sativa polyphenol extracts. Eur. Food Res. Technol. 2009, 230, 353-359. [CrossRef]

29. Mosmann, T. Rapid colorimetric assay for cellular growth and survival: Application to proliferation and cytotoxicity assays. $J$. Immunol. Methods 1983, 65, 55-63. [CrossRef]

30. Rodrigues, M.J.; Gangadhar, K.N.; Vizzeto-Duarte, C.; Wubshet, S.G.; Nyberg, N.T.; Barreira, L.; Varela, J.; Custódio, L. Maritime Halophyte Species from Southern Portugal as Sources of Bioactive Molecules. Mar. Drugs 2014, 12, 2228-2244. [CrossRef] [PubMed]

31. Miranda, K.M.; Espey, M.G.; Wink, D.A. A Rapid, Simple Spectrophotometric Method for Simultaneous Detection of Nitrate and Nitrite. Nitric Oxide 2001, 5, 62-71. [CrossRef]

32. Smoliak, S.; Bezeau, L.M. Chemical composition and in vitro digestibility of range forage plants of the stipa-bouteloua prairie. Can. J. Plant Sci. 1966, 47, 161-167. [CrossRef]

33. Barreira, L.; Resek, E.; Rodrigues, M.J.; Rocha, M.I.; Pereira, H.; Bandarra, N.; Da Silva, M.M.; Varela, J.; Custódio, L. Halophytes: Gourmet food with nutritional health benefits? J. Food Compos. Anal. 2017, 59, 35-42. [CrossRef]

34. Glenn, E.P. Relationship between cation accumulation and water content of salt-tolerant grasses and a sedge. Plant Cell Environ. 1987, 10, 205-212.

35. Reddy, A.R.; Chaitanya, K.V.; Vivekanandan, M. Drought-induced responses of photosynthesis and antioxidant metabolism in higher plants. J. Plant Physiol. 2004, 161, 1189-1202. [CrossRef] [PubMed]

36. Heuzé, V.; Tran, G.; Delagarde, R.; Lebas, F. Bermuda Grass (Cynodon dactylon). Feedipedia, a Programme by INRAE, CIRAD, AFZ and FAO. Available online: https://www.feedipedia.org/node/471 (accessed on 20 October 2015).

37. Fancote, C.R.; Norman, H.C.; Williams, I.H.; Masters, D.G. Cattle performed as well as sheep when grazing a river saltbush (Atriplex amnicola)-based pasture. Anim. Prod. Sci. 2009, 49, 998-1006. [CrossRef]

38. Heuzé, V.; Tran, G.; Hassoun, P.; Lebas, F. Saltbush (Atriplex halimus). Feedipedia, a Programme by INRAE, CIRAD, AFZ and FAO. Available online: https:/ / www.feedipedia.org/node/24708 (accessed on 8 July 2019).

39. Serrano, J.; Shahidian, S.; Da Silva, J.M.; Paixão, L.; Carreira, E.; Carmona-Cabezas, R.; Nogales-Bueno, J.; Rato, A.E. Evaluation of Near Infrared Spectroscopy (NIRS) and Remote Sensing (RS) for Estimating Pasture Quality in Mediterranean Montado Ecosystem. Appl. Sci. 2020, 10, 4463. [CrossRef]

40. Catling, P.M.; Mcelroy, A.R.; Spicer, K.W. Potential forage value of some eastern Canadian sedges (Cyperacerae: Carex). J. Range Manag. 1994, 47, 226-230. [CrossRef]

41. Adesogan, A.T.; Arriola, K.G.; Jiang, Y.; Oyebade, A.; Paula, E.M.; Pech-Cervantes, A.A.; Romero, J.J.; Ferraretto, L.F.; Vtas, D. Symposium review: Technologies for improving fiber utilization. J. Dairy Sci. 2019, 102, 1-30. [CrossRef]

42. Forejtová, J.; Lád, F.; Třináctý, J.; Richter, M.; Gruber, L.; Doležal, P.; Homolka, P.; Pavelek, L. Comparison of organic matter digestibility determined by in vivo and in vitro methods. Czech J. Anim. Sci. 2005, 50, 47-53. [CrossRef]

43. Reed, J.D. Nutritional toxicology of tannins and related polyphenols in forage legumes. J. Anim. Sci. 1995, 73, 1516-1528. [CrossRef] 
44. Aerts, R.J.; Barry, T.N.; McNabb, W.C. Polyphenols and agriculture: Beneficial effects of proanthocyanidins in forages. Agric. Ecosyst. Environ. 1999, 75, 1-12. [CrossRef]

45. Mueller-Harvey, I.; Bee, G.; Dhome-Meier, F.; Hoste, H.; Karonen, M.; Kölliker, R.; Lüscher, A.; Niderkorn, V.; Pellikaan, W.F.; Salminen, J.P.; et al. Benefits of Condensed Tannins in Forage Legumes Fed to Ruminants: Importance of Structure, Concentration, and Diet Composition. Crop. Sci. 2018, 58, 1-25. [CrossRef]

46. National Research Council. Mineral Tolerance of Animals, 2nd ed.; The National Academies Press: Washington, DC, USA, 2005.

47. Spears, J.W. Minerals in Forages in Forage Quality, Evaluation, and Utilization; Fahey, G.C., Jr., Ed.; American Society of Agronomy, Crop Science Society of America, Soil Science Society of America: Madison, WI, USA, 1994.

48. Norman, H.C.; Masters, D.G.; Barrett-Lennard, E.G. Halophytes as forages in saline landscapes: Interactions between plant genotype and environment change their feeding value to ruminants. Environ. Exp. Bot. 2013, 92, 96-109. [CrossRef]

49. McDowell, L.R.; Arthington, J.D. Minerals for Grazing Ruminants in Tropical Regions, 4th ed.; Institute of Food and Agricultural Sciences, University of Florida: Gainesville, FL, USA, 2005.

50. McDowell, L.R.; Valle, G. Major Minerals in Forages. In Forage Evaluation in Ruminant Nutrition; Givens, D.I., Owen, E.O., Axford, R.F.E., Omed, H.M., Eds.; CABI Publishing: Wallingford, UK, 2000; pp. 373-397.

51. Norman, H.C.; Duncan, E.G.; Masters, D.G. Halophytic shrubs accumulate minerals associated with antioxidant pathways. Grass Forage Sci. 2019, 74, 345-355. [CrossRef]

52. MacPherson, A. Trace-Mineral Status of Forages. In Forage Evaluation in Ruminant Nutrition; Givens, D.I., Owen, E., Axford, R.F.E., Omed, H.M., Eds.; CABI Publishing: Wallingford, UK, 2000; pp. 345-371.

53. Stein, R.J. Relationships between soil and leaf mineral composition are element-specific, environment-dependent and geographically structured in the emerging model Arabidopsis helleri. New Phytol. 2017, 213, 1274-1286. [CrossRef]

54. Kähkönen, M.P.; Hopia, A.I.; Vuorela, H.J.; Rauha, J.P.; Pihlaja, K.; Kujala, T.S.; Heinonen, M. Antioxidant Activity of Plant Extracts Containing Phenolic Compounds. J. Agric. Food Chem. 1999, 47, 3954-3962. [CrossRef] [PubMed]

55. Mishra, S.; Tripathi, A.; Tripathi, D.K.; Chauhan, D.K. Role of sedges (Cyperaceae) in wetlands, environmental cleaning and as food material: Possibilities and future perspectives. In Plant-Environment Interaction: Responses and Approaches to Mitigate Stress; Azooz, M.M., Ahmad, P., Eds.; John Wiley \& Sons, Ltd.: Hoboken, NJ, USA, 2016.

56. Sievers, C. Nuts for dinner? Cladium mariscus in the Middle Stone Age at Sibudu, South Africa. Trans. R. Soc. S. Afr. 2015, 70, 213-218. [CrossRef]

57. Isah, T. Stress and defense responses in plant secondary metabolites production. Biol. Res. 2019, 52, 39. [CrossRef] [PubMed]

58. Sharma, A.; Shahzad, B.; Rehman, A.; Bhardwaj, R.; Landi, M.; Zheng, B. Response of Phenylpropanoid Pathway and the Role of Polyphenols in Plants under Abiotic Stress. Molecules 2019, 24, 2452. [CrossRef] [PubMed]

59. Jerónimo, E.; Pinheiro, C.; Lamy, E.; Dentinho, M.T.; Sales-Baptista, E.; Lopes, O.; Capela e Silva, F. Tannins in Ruminant Nutrition: Impact on animal performance and quality of edible products. In Tannins: Biochemistry, Food Sources and Nutritional Properties; Combs, C.A., Ed.; Nova Science Publishers Inc.: New York, NY, USA, 2016.

60. Del Moral, R. On the variability of chlorogenic acid concentration. Oecologia 1972, 9, 289-300. [CrossRef]

61. Camacho-Cristóbal, J.; Lunar, L.; Lafont, F.; Baumert, A.; González-Fontes, A. Boron deficiency causes accumulation of chlorogenic acid and caffeoyl polyamine conjugates in tobacco leaves. J. Plant Physiol. 2004, 161, 879-881. [CrossRef] [PubMed]

62. Clé, C.; Hill, L.M.; Niggeweg, R.; Martin, C.R.; Guisez, Y.; Prinsen, E.; Jansen, M.A.K. Modulation of chlorogenic acid biosynthesis in Solanum lycopersicum; consequences for phenolic accumulation and UV-tolerance. Phytochemistry 2008, 69, 2149-2156. [CrossRef]

63. Meot-Duros, L.; Magné, C. Antioxidant activity and phenol content of Crithmum maritimum L. leaves. Plant Physiol. Biochem. 2009, 47,37-41. [CrossRef]

64. Chini, A.; Grant, J.J.; Seki, M.; Shinozaki, K.; Loake, G.J. Drought tolerance established by enhanced expression of the CCI-NBSLRR gene, ADR1, requires salicylic acid, EDS1 and ABI1. Plant J. 2004, 38, 810-822. [CrossRef]

65. Metwally, A.; Finkemeier, I.; Georgi, M.; Dietz, K.J. Salicylic Acid Alleviates the Cadmium Toxicity in Barley Seedlings. Plant Physiol. 2003, 132, 272-281. [CrossRef] [PubMed]

66. Borsani, O.; Valpuesta, V.; Botella, A. Evidence for a Role of Salicylic Acid in the Oxidative Damage Generated by NaCl and Osmotic Stress in Arabidopsis Seedlings. Plant Physiol. 2001, 126, 1024-1030. [CrossRef] [PubMed]

67. Larkindale, J.; Knight, M.R. Protection against Heat Stress-Induced Oxidative Damage in Arabidopsis Involves Calcium, Abscisic Acid, Ethylene, and Salicylic Acid. Plant Physiol. 2002, 128, 682-695. [CrossRef]

68. Kumar, N.; Pruthi, V. Potential applications of ferulic acid from natural sources. Biotechnol. Rep. 2014, 4, 86-93. [CrossRef] [PubMed]

69. Cheemanapalli, S.; Mopuri, R.; Golla, R.; Anuradha, C.M.; Chitta, S.K. Syringic acid (SA)—A Review of Its Occurrence, Biosynthesis, T Pharmacological and Industrial Importance. Biomed. Pharmacother. 2018, 108, 547-557.

70. Bhardwaj, R.; Handa, N.; Sharma, R.; Kaur, H.; Kohli, S.; Kumar, V.; Kaur, P. Lignins and abiotic stress: An overview. In Physiological Mechanisms and Adaptation Strategies in Plants under Changing Environment; Ahmad, P., Wani, M.R., Eds.; Springer: New York, NY, USA, 2014.

71. Naveed, M.; Hejazi, V.; Abbas, M.; Kamboh, A.A.; Khan, G.J.; Shumzaid, M.; Ahmad, F.; Babazadeh, D.; FangFang, X.; ModarresiGhazani, F.; et al. Chlorogenic acid (CGA): A pharmacological review and call for further research. Biomed. Pharmacother. 2018, 97, 67-74. [CrossRef]

72. Kim, J.K.; Park, S.U. A recent overview on the biological and pharmacological activities of ferulic acid. EXCLI J. 2019, 18, 132-138. 
73. Di Fernando, M.; Brunetti, C.; Agati, G.; Tattini, M. Multiple functions of polyphenols in plants inhabiting unfavorable Mediterranean areas. Environ. Exp. Bot. 2014, 103, 107-116. [CrossRef]

74. Léon-Chan, R.G.; López-Meyer, M.; Osuna-Enciso, T.; Sañudo-Barajas, A.; Heredia, J.B.; Léon-Félix, J. Low temperature and ultraviolet-B radiation affect chlorophyll content and induce the accumulation of UV-B-absorbing and antioxidant compounds inbell pepper (Capsicum annuum) plants. Environ. Exp. Bot. 2017, 139, 143-151. [CrossRef]

75. Park, C.M.; Song, Y.-S. Luteolin and luteolin-7-O-glucoside inhibit lipopolysaccharide-induced inflammatory responses through modulation of NF-KB/AP-1/PI3K-Akt signaling cascades in RAW 264.7 cells. Nutr. Res. Pr. 2013, 7, 423-429. [CrossRef] [PubMed]

76. Sinz, S.; Kunz, C.; Liesegang, A.; Braun, U.; Marquardt, S.; Soliva, C.R.; Kreuzer, M. In Vitro Bioactivity of Various Pure Flavonoids in Ruminal Fermentation, with Special Reference to Methane Formation. Czech J. Anim. Sci. 2018, 63, $293-304$.

77. Klongsiriwet, C.; Quijada, J.; Williams, A.R.; Mueller-Harvey, I.; Williamson, E.M.; Hoste, H. Synergistic inhibition of Haemonchus contortus exsheathment by flavonoid monomers and condensed tannins. Int. J. Parasitol. Drugs Drug Resist. 2015, 5, 127-134. [CrossRef] [PubMed]

78. Celi, P.; Gabai, G. Oxidant/antioxidant balance in animal nutrition and health: The role of protein oxidation. Front. Vet. Sci. 2015, 2, 48. [CrossRef]

79. Chauhan, S.S.; Celi, P.; Ponnampalam, E.N.; Leury, B.J.; Liu, F.; Dunshea, F.R. Antioxidant dynamics in the live animal and implications for ruminant health and product (meat/milk) quality: Role of vitamin E and selenium. Anim. Prod. Sci. 2014, 54, 1525-1536. [CrossRef]

80. McGrath, J.; Duval, M.D.; Tamassia, L.F.M.; Kindermann, M.; Stemmler, R.T.; Gouvea, V.N.; Acedo, T.S.; Immig, I.; Williams, S.N.; Celi, P. Nutritional strategies in ruminants: A lifetime approach. Res. Vet. Sci. 2018, 116, 28-39. [CrossRef]

81. Gonzalez-Maldonado, J.; Martínez-Aispuro, J.A.; Rangel-Santos, R.; Rodriguez-de Lara, R.R. Antioxidant supplementation in female ruminants during the periconceptional period: A review. Rev. Colomb. Cienc. Pecu. 2018, 31, 245-255. [CrossRef]

82. Celi, P. The role of oxidative stress in small ruminants' health and production. Rev. Bras. Zootec. 2010, 39, 348-363. [CrossRef]

83. Sordillo, L.M.; Aitken, S.L. Impact of oxidative stress on the health and immune function of dairy cattle. Vet. Immunol. Immunopathol. 2009, 128, 104-109. [CrossRef]

84. Mazur, M.; Zwyrzykowska-Wodzińska, A.; Wojtas, E.; Zachwieja, A.; Salejda, A.M. Effect of yerba mate (Ilex paraguariensis A. St.-Hil.) supplementation on oxidative stress in ruminants. Chil. J. Agric. Res. 2019, 79, 316-322.

85. Schlesier, K.; Harwat, M.; Böhm, V.; Bitsch, R. Assessment of Antioxidant Activity by Using Different In Vitro Methods. Free Radic. Res. 2002, 36, 177-187. [CrossRef]

86. Pilluzza, G.; Bullita, S. Correlations between phenolic content and antioxidant properties in twenty-four plant species of traditional ethnoveterinary use in the Mediterranean area. Pharm. Biol. 2011, 49, 240-247. [CrossRef]

87. Biswas, S.K. Does the Interdependence between Oxidative Stress and Inflammation Explain the Antioxidant Paradox? Oxidative Med. Cell. Longev. 2016, 2016, 5698931. [CrossRef] [PubMed]

88. Hwang, S.J.; Kim, Y.W.; Park, Y.; Lee, H.J.; Kim, K.W. Anti-inflammatory effects of chlorogenic acid in lipopolysaccharidestimulated RAW 264.7 cells. Inflamm. Res. 2014, 63, 81-90. [CrossRef] [PubMed]

89. Li, T.; Liu, X.; Liu, J.; Li, D. Synergistic anti-inflammatory effects of quercetin and catechin via inhibiting activation of TLR4MyD88-mediated NF-кB and MAPK signaling pathways. Phytotherapy Res. 2019, 33, 756-767. [CrossRef] [PubMed] 